\title{
Studi CFD mengenai Pengaruh Sifat Fisis Fluida terhadap Karakteristik Counter-Current Flow Limitation pada Pipa Horizontal
}

\author{
A S. Pratama*, Indarto dan Deendarlianto \\ Departemen Teknik Mesin dan Industri, Fakultas Teknik, Universitas Gadjah Mada. \\ JI. Grafika No. 2, Kompleks UGM, Yogyakarta 55281, Indonesia \\ *E-mail: andhika.s.p@mail.ugm.ac.id
}

\begin{abstract}
Abstrak
Tujuan penelitian ini ialah untuk mempelajari pengaruh densitas cairan, viskositas cairan, dan densitas gas terhadap karakteristik counter current flow limitation atau flooding pada pipa horizontal. Analisis numerik dilakukan menggunakan software CFD Ansys Fluent 2020 R2 student version dengan menerapkan model volume of fluid (VOF). Aparatus penelitian yang digunakan ialah geometri pipa hot leg reaktor PWR tipe German Konvoi skala 1/30 yang terdiri dari reactor pressure vessel, pipa hot leg, dan steam generator. Pipa hot leg yang digunakan memiliki diameter dalam D = $25,4 \mathrm{~mm}$ dan panjang pipa horizontal $\mathrm{L}=635 \mathrm{~mm}(\mathrm{~L} / \mathrm{D}=25)$. Cairan yang digunakan ialah air, kloroform, larutan gliserin 10\%, dan propil asetat, sedangkan gas yang digunakan ialah udara dan uap air. Hasil penelitian menunjukkan bahwa peningkatan densitas cairan menyebabkan peningkatan kecepatan superficial flooding gas, serta menyebabkan pergeseran bydraulic jump dan locus of slugging menjauhi belokan. Hasil dari peningkatan viskositas cairan menunjukkan pola yang berkebalikan dibandingkan hasil dari peningkatan densitas cairan. Penurunan densitas gas menyebabkan flooding terjadi pada kecepatan superficial gas yang lebih tinggi, serta menyebabkan pergeseran bydraulic jump dan locus of slugging menjauhi belokan.
\end{abstract}

Kata kunci : Counter-current flow limitation, Sifat fisis fluida, Computational fluid dynamics.

\begin{abstract}
The purpose of this research was to study the effect of liquid density, liquid viscosity, and gas density on the characteristics of counter-current flow limitation or flooding in horizontal pipes. Numerical analysis was carried out using CFD software Ansys Fluent 2020 R2 student version by applying the volume of fluid (VOF) model. The research apparatus used was the geometry of 1/30 downscale of PWR hot leg pipe of the German Convoy type reactor which consisted of a reactor pressure vessel, hot leg pipe, and a steam generator. The inner diameter of the hot leg pipe was $\mathrm{D}=25,4 \mathrm{~mm}$ and the length of the horizontal pipe was $\mathrm{L}=635 \mathrm{~mm}(\mathrm{~L} / \mathrm{D}=25)$. The liquids used were water, chloroform, 10\% glycerin solution, and propyl acetate, while the gases used were air and water vapor. The results showed that an increase in liquid density caused an increase in the gas superficial flooding velocities, as well as a shift in the hydraulic jump and locus of slugging away from the bend. The result of increasing the viscosity of the liquid showed the opposite pattern compared to the result of increasing the density of the liquid. The decrease in gas density caused flooding to occur at higher superficial gas velocities and caused a shift in the hydraulic jump and locus of slugging away from the bend.
\end{abstract}

Keywords : Counter-current flow limitation, Fluid properties, Computational fluid dynamics. 


\section{PENDAHULUAN}

Pada pressurized water reactor (PWR), coolant pada siklus primer berfungsi sebagai media pemindah kalor dari bahan bakar nuklir di reactor pressure vessel (RPV) menuju feedwater pada sistem sekunder. Perpindahan kalor ini terjadi di steam generator (SG). Kalor yang diterima oleh feedwater akan menyebabkan feedwater berubah fase menjadi uap. Uap tersebut digunakan untuk memutar turbin dan generator listrik. Pada kondisi operasi normal, coolant dijaga pada fase cair pada tekanan sekitar $15 \mathrm{MPa}$ (Deendarlianto et al., 2012). Ketika terjadi kebocoran pada sistem primer, tekanan pada sistem primer akan mengalami penurunan. Ketika tekanan sistem primer lebih rendah dibandingkan tekanan saturasi coolant, coolant akan mengalami perubahan fase menjadi uap. Kondisi ini disebut sebagai loss-of-coolant accident (LOCA). Uap akan mengalir menuju steam generator ketika level coolant di reactor pressure vessel lebih rendah dibandingkan hot leg. Uap akan mengembun di steam generator dan sebagian kondensat akan mengalir menuju reactor pressure vessel. Aliran uap dan kondensat yang berrsifat berlawanan arah ini membentuk konfigurasi aliran dua fase cair-gas berlawanan arah (counter-current liquid-gas two phase flow). Keberadaan konfigurasi aliran ini membentuk proses pendinginan reflux condensation yang hanya dapat stabil pada kecepatan cairan dan gas tertentu. Ketika kecepatan aliran uap meningkat, aliran kondensat menuju RPV akan berkurang dan sebagian kondensat akan mengalir kembali menuju SG. Fenomena ini disebut sebagai counter-current flow limitation (CCFL) atau flooding (Deendarlianto et al., 2011). Konfigurasi aliran dua fase berlawanan arah pada siklus primer PWR ditampilkan pada Gambar 1.

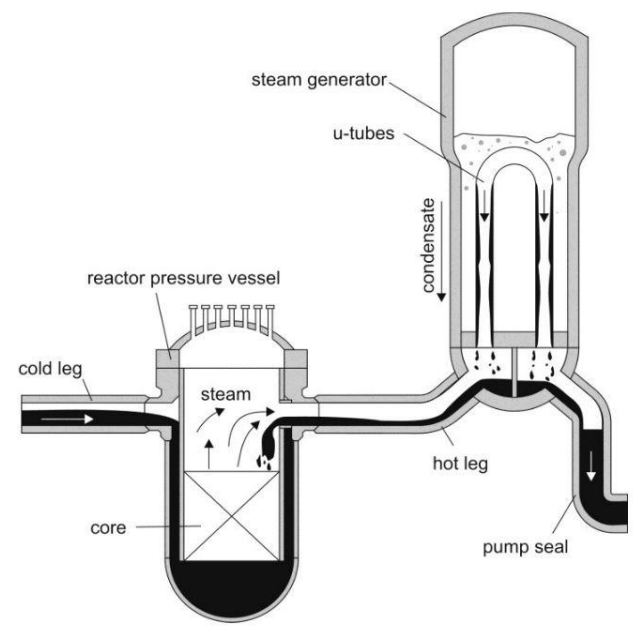

Gambar 1. Fenomena aliran dua fase cair-gas berlawanan arah ketika terjadi LOCA pada PWR (Seidel et al., 2011)

Salah satu parameter yang mempengaruhi karakteristik flooding ialah sifat fisis fluida (fluid properties). Terkait dengan surface tension, Suzuki dan Ueda (1977) menemukan bahwa kecepatan flooding gas mencapai nilai maksimum ketika nilai surface tension mendekati $0,05 \mathrm{~N} / \mathrm{m}$. Ousaka et al. (2006) dan Deendarlianto et al. (2010) melakukan penelitian dengan cara memvariasikan surface tension sembari menjaga densitas dan viskositas cairan pada nilai yang konstan dan menemukan bahwa peningkatan surface tension menyebabkan peningkatan kecepatan flooding gas. Hasil yang serupa juga ditemui oleh Pantzali et al. (2007) walaupun pengaruh surface tension yang ditemukan lebih kecil dibandingkan viskositas cairan. Mouza et al. (2005) menemukan bahwa surface tension memiliki stabilizing effect pada permukaan cairan. Terkait dengan viskositas cairan, Kinoshita et al. (2011) menemukan bahwa peningkatan viskositas cairan menyebabkan 
penurunan kecepatan superficial flooding gas dan pengaruh viskositas tidak ditemukan pada kecepatan superficial cairan yang rendah. Penurunan kecepatan superficial flooding gas akibat peningkatan viskositas cairan juga ditemukan oleh Pantzali et al. (2007) dan Prayitno et al. (2012), tetapi hasil yang berkebalikan ditemukan oleh Suzuki dan Ueda (1977).

Ohnuki (1986) melakukan penelitian dengan menggunaan kombinasi fluida air-udara dan air-uap air dan memperoleh hasil yang mana tidak ditemukannya perbedaan grafik flooding antara kombinasi fluida air-udara dan air-uap air. Berdasarkan hal tersebut, disimpulkan bahwa kombinasi fluida tidak mempengaruhi grafik flooding. Zapke dan Kroeger (1996) memperoleh hasil yang berbeda yang mana densitas fluida memiliki pengaruh yang lebih besar dibandingkan surface tension dan viskositas cairan untuk pipa vertikal.

Hasil literature review menunjukkan bahwa terdapat beberapa hasil penelitian yang saling berkebalikan. Hal ini dapat disebabkan oleh penelitian mengenai sifat fisis fluida belum dilaksanakan secara sistematis, yaitu dengan menjaga sifat fisis fluida yang lain konstan ketika salah satu sifat fisis fluida diteliti. Penelitian ini bertujuan untuk mempelajari pengaruh densitas cairan, viskositas cairan, dan densitas gas terhadap karakteristik CCFL pada pipa horizontal. Penelitian mengenai surface tension yang telah dilakukan oleh Ousaka et al. (2006) dan Deendarlianto et al. (2010) bersifat sistematis sehingga surface tension tidak dibahas dalam penelitian ini. Pembahasan mengenai pengaruh densitas cairan akan dilakukan terlebih dahulu, diikuti oleh pembahasan mengenai pengaruh viskositas cairan dan densitas gas. Pada masingmasing bagian, grafik CCFL akan dibahas terlebih dahulu. Selanjutnya, pembahasan dilakukan terhadap proses terjadinya flooding melalui visualisasi pola aliran dan pengaruh flooding terhadap pressure difference antara RPV dan SG, kecepatan superficial delivered cairan, dan volume cairan yang memasuki RPV. Selanjutnya, pembahasan akan dilakukan terhadap locus of slugging dan diakhiri dengan penjelasan mengenai bagaimana sifat-sifat fisis fluida tersebut mempengaruhi karakteristik CCFL.

\section{METODE PENELITIAN}

Geometri yang digunakan pada penelitian ini adalah geometri pipa hot leg reaktor PWR tipe German Konvoi skala 1/30. Simulasi dilakukan secara tiga dimensi. Aparatus penelitian ini terdiri dari reactor pressure vessel, hot leg, dan steam generator. Hot leg tersusun dari pipa horizontal dan belokan. Dimensi yang digunakan pada penelitian ini mengacu pada aparatus yang digunakan pada penelitian Badarudin (2018). Hot leg memiliki diameter dalam D = 25,4 mm dengan panjang pipa horizontal $\mathrm{L}=635 \mathrm{~mm}(\mathrm{~L} / \mathrm{D}=25)$. Sudut kemiringan hot leg (dihitung dari sudut antara pipa horizontal dengan sumbu horizontal) yang digunakan ialah $\theta=0^{\circ}$. Belokan memiliki sudut $\beta=50^{\circ}$ dengan radius dalam dan luar masing-masing 67,3 mm dan 97,2 $\mathrm{mm}$. Grid awal yang digunakan pada penelitian ini berjumlah 72.511 cells dengan grid pada penampang hot leg berjumlah 329 cells. Penelitian yang dilakukan Kinoshita et al. (2011) dan Murase et al. (2012) menunjukkan bahwa grid dengan rentang ukuran 59.000 hingga 120.000 cells cukup untuk digunakan pada simulasi CCFL. Grid independence test dilakukan dengan meningkatkan jumlah cell menjadi 1,5 kali jumlah cell awal (108.094 cells). Geometri dan grid yang digunakan pada penelitian ini ditampilkan pada Gambar 2. 


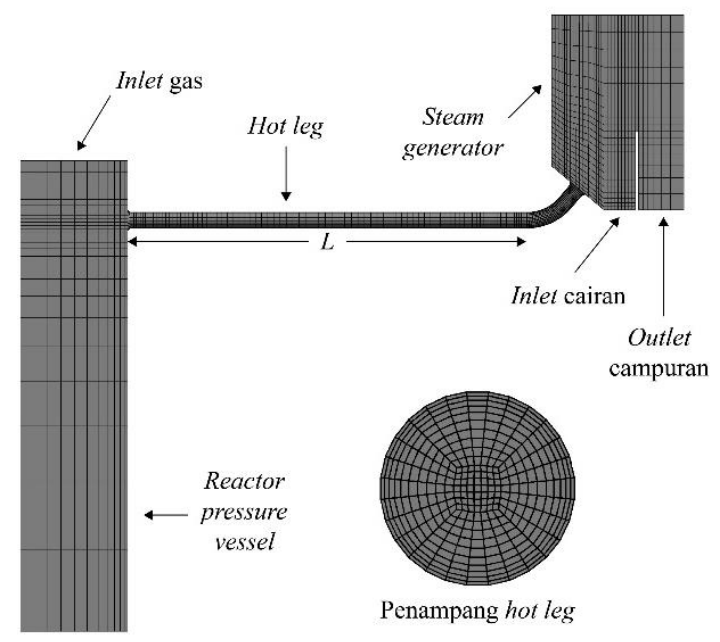

Gambar 2. Geometri bagian bot leg reaktor PWR tipe German Konvoi skala 1/30 (mengikuti aparatus penelitian Badarudin (2018)) dan grid komputasi

Cairan diinjeksikan melalui bagian bawah SG dan gas diinjeksikan melalui bagian atas RPV. Cairan dan gas keluar dari aparatus penelitian melalui outlet yang terletak pada bagian bawah SG dibalik baffle. Boundary condition yang digunakan pada lokasi penginjeksian cairan dan gas ialah velocity inlet dan boundary condition yang digunakan pada keluaran cairan dan gas ialah pressure outlet. Dinding aparatus dimodelkan sebagai stationary wall dengan kondisi no-slip.

Analisis numerik dilakukan dengan menggunakan komputer simulasi pada Lab. Mekanika Fluida, Departemen Teknik Mesin dan Industri, Fakultas Teknik, Universitas Gadjah Mada. Komputer ini memiliki spesifikasi CPU 6 cores dengan clock speed 3,2 GHz dan RAM 32 GB. Software yang digunakan untuk melakukan analisis numerik adalah Ansys Fluent 2020 R2 student version. Model aliran dua fase yang digunakan ialah volume of fluid (VOF). Tiga model turbulensi yang akan dibandingkan ialah standard k-epsilon, standard k-omega, dan k-omega SST. Grafik flooding yang diperoleh dari ketiga model tersebut dibandingkan dengan grafik flooding yang diperoleh pada penelitian Badarudin (2018) untuk panjang hot leg $\mathrm{L}=635 \mathrm{~mm}$. Persamaan konservasi momentum diselesaikan menggunakan second-order upwind, sedangkan turbulence kinetic energy dan dissipation rate diselesaikan dengan menggunakan first-order upwind. Fraksi volume diselesaikan dengan metode geo-reconstruction. Algoritma penyelesaian SIMPLE digunakan untuk menyelesaikan persamaan Navier-Stokes dan kontinuitas. Analisis dilakukan secara transient dan adiabatik dengan time step divariasikan dari 0,5-4 ms, tergantung stabilitas perhitungan. Jumlah iterasi yang dilakukan tiap time step ialah 20 iterasi. Flow time yang digunakan untuk tiap perubahan nilai kecepatan superficial gas ialah $15 \mathrm{~s}$.

Cairan yang digunakan ialah air, larutan gliserin 10\%, propil asetat, dan kloroform. Gas yang digunakan adalah udara dan uap air. Variasi nilai dari viskositas cairan, densitas cairan, dan densitas gas yang digunakan ditampilkan pada Tabel 1. Kecepatan superficial cairan yang digunakan pada ialah $\mathrm{JL}=0,01 \mathrm{~m} / \mathrm{s} ; 0,026 \mathrm{~m} / \mathrm{s} ; 0,046 \mathrm{~m} / \mathrm{s} ; 0,066 \mathrm{~m} / \mathrm{s} ; 0,085 \mathrm{~m} / \mathrm{s} ;$ dan 0,102 $\mathrm{m} / \mathrm{s}$. Kecepatan superficial gas divariasikan dari $0 \mathrm{~m} / \mathrm{s}$ hingga mencapai flooding dengan $\Delta \mathrm{JG}=$ $0,1645 \mathrm{~m} / \mathrm{s}$. 
A.S. Pratama et al. / Journal of Mechanical Design and Testing 3(2), (2021), 118-132

Tabel 1. Sifat Fisis Cairan dan Gas $(\mathrm{P}=1 \mathrm{~atm})$

\begin{tabular}{|c|c|c|c|c|}
\hline $\begin{array}{l}\text { Jenis } \\
\text { Fluida }\end{array}$ & Nama Fluida & $\begin{array}{l}\text { Densitas } \\
\left(\mathrm{kg} / \mathrm{m}^{3}\right)\end{array}$ & $\begin{array}{l}\text { Viskositas } \\
\text { (Pa.s) }\end{array}$ & $\begin{array}{l}\text { Surface } \\
\text { tension } \\
(\mathrm{N} / \mathrm{m})\end{array}$ \\
\hline \multirow{4}{*}{ Cairan } & Air & 999 & $1,00 \times 10^{-3}$ & $72,7 \times 10^{-3}$ \\
\hline & $\begin{array}{l}\text { Larutan gliserin 10\% } \\
\text { (Glycerine Producers' } \\
\text { Association, 1963) }\end{array}$ & 1022,1 & $1,31 \times 10^{-3}$ & $71,8 \times 10^{-3}$ \\
\hline & $\begin{array}{l}\text { Propil asetat (Haynes, } \\
\text { 2016) }\end{array}$ & 883 & $0,54 \times 10^{-3}$ & $23,9 \times 10^{-3}$ \\
\hline & $\begin{array}{c}\text { Kloroform (Haynes, } \\
2016)\end{array}$ & 1480 & $0,54 \times 10^{-3}$ & $26,7 \times 10^{-3}$ \\
\hline \multirow{2}{*}{ Gas } & Udara & 1,225 & $1,79 \times 10^{-5}$ & - \\
\hline & Uap air & 0,554 & $1,34 \times 10^{-5}$ & - \\
\hline
\end{tabular}

Data kecepatan superficial flooding gas $\left(\mathrm{J}_{\mathrm{G}}\right)$ ditentukan pada saat onset of flooding yang ditandai dengan terjadinya penurunan kecepatan superficial cairan yang memasuki reactor pressure

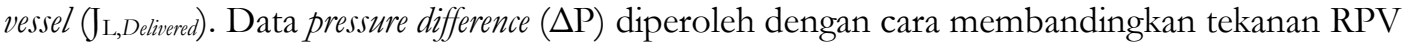
dengan tekanan SG. Gambar pola aliran diperoleh dengan cara memotong aparatus penelitian menjadi simetris terhadap permukaan x-y. Gambar tersebut berupa kontur fraksi volume. Locus of slugging (lokasi pembentukan slug awal) ditentukan dengan mengukur lokasi slug awal relatif terhadap lokasi belokan.

\section{HASIL DAN PEMBAHASAN}

\subsection{Hasil Grid Independence Test}

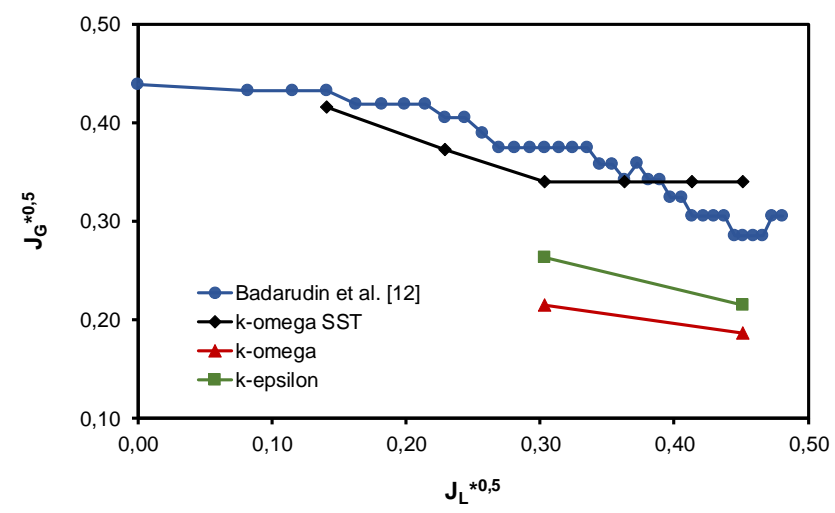

Gambar 3. Perbandingan data onset of flooding untuk air-udara hasil simulasi dengan grafik Badarudin (2018)

Gambar 3 menunjukkan data onset of flooding untuk air-udara yang diperoleh menggunakan model turbulensi standard k-epsilon, standard k-omega, dan k-omega SST. Ukuran mesh yang digunakan ialah 72.511 cells. Data tersebut dibandingkan dengan data yang didapatkan oleh Badarudin (2018). Data tersebut disajikan dalam kecepatan superficial tak berdimesi Wallis (1969):

$$
\mathrm{J}_{\mathrm{k}}^{*}=\mathrm{J}_{\mathrm{k}}\left(\frac{\rho_{\mathrm{k}}}{g \mathrm{D}\left(\rho_{\mathrm{L}}-\rho_{\mathrm{G}}\right)}\right)^{0,5}(\mathrm{k}=\mathrm{G} \text { atau } \mathrm{L})
$$


Hasil yang diperoleh menunjukkan bahwa data hasil perhitungan numerik menggunakan model k-omega SST mendekati data acuan. Model standard k-omega dan standard k-epsilon memberikan data kecepatan superficial gas yang jauh lebih rendah dibandingkan data yang diperoleh dengan menggunakan k-omega SST pada kecepatan superficial cairan yang sama. Berdasarkan data yang diperoleh dari ketiga model terebut, model turbulensi yang akan digunakan seterusnya ialah model k-omega SST.

Grid independence test dilakukan dengan membandingkan hasil yang diperoleh menggunakan ukuran mesh 72.511 cells dan 108.094 cells (sekitar 1,5 kali ukuran mesh awal). Gambar 4 menunjukkan data variasi parameter aliran terhadap waktu dari kedua ukuran mesh pada $\mathrm{J}_{\mathrm{L}}=0,01 \mathrm{~m} / \mathrm{s}$. Bagian atas dari gambar menunjukkan volume cairan yang berada di dalam RPV dan kecepatan superficial cairan yang mengalir ke dalam RPV (J L,Delivered), sedangkan bagian bawah dari gambar menunjukkan perbedaan tekanan antara RPV dan SG $(\Delta \mathrm{P})$ dan kecepatan superficial gas yang diinjeksikan $\left(\mathrm{J}_{\mathrm{G}}\right)$. Hasil yang diperoleh menunjukkan bahwa kedua ukuran mesh memberikan data onset of flooding yang sama dan memberikan variasi volume cairan di RPV, $\mathrm{J}_{\mathrm{L}}$, Delivered, $\Delta \mathrm{P}$, dan $\mathrm{J}_{\mathrm{G}}$ yang serupa. Pada $\mathrm{J}_{\mathrm{L}}=0,01 \mathrm{~m} / \mathrm{s}$, kedua ukuran mesh memberikan kecepatan superficial flooding gas $\mathrm{J}_{\mathrm{G}}=2,47 \mathrm{~m} / \mathrm{s}$. Fluktuasi $\Delta \mathrm{P}$ pada mesh berukuran 72.511 cells (Gambar 4 .a) relatif lebih besar dibandingkan fluktuasi tekanan pada mesh berukuran 108.094 cells (Gambar 4.b), tetapi hal tersebut tidak signifikan. Berdasarkan hasil tersebut, mesh berukuran 72.511 cells akan digunakan untuk seterusnya pada penelitian ini.

\subsection{Pengaruh Densitas Cairan terhadap Karakteristik CCFL}

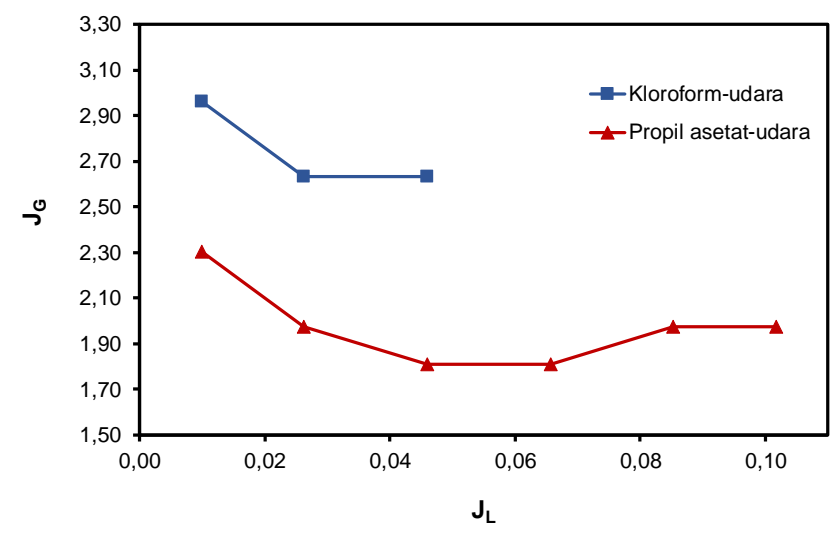

Gambar 5. Data onset of flooding kloroform-udara dan propil asetat

Gambar 5 menunjukkan data onset of flooding antara kloroform-udara dan propil asetatudara. Data onset of flooding dinyatakan dalam kecepatan superficial cairan $\left(\mathrm{J}_{\mathrm{L}}\right)$ dan kecepatan superficial gas $\left(\mathrm{J}_{\mathrm{G}}\right)$. Hasil perhitungan numerik menunjukkan bahwa pada kecepatan superficial cairan yang sama, kloroform menghasilkan kecepatan superficial flooding gas yang lebih tinggi dibandingkan propil asetat. Berdasarkan hal tersebut, peningkatan densitas cairan akan menyebabkan peningkatan kecepatan superficial flooding gas. 
A.S. Pratama et al. / Journal of Mechanical Design and Testing 3(2), (2021), 118-132

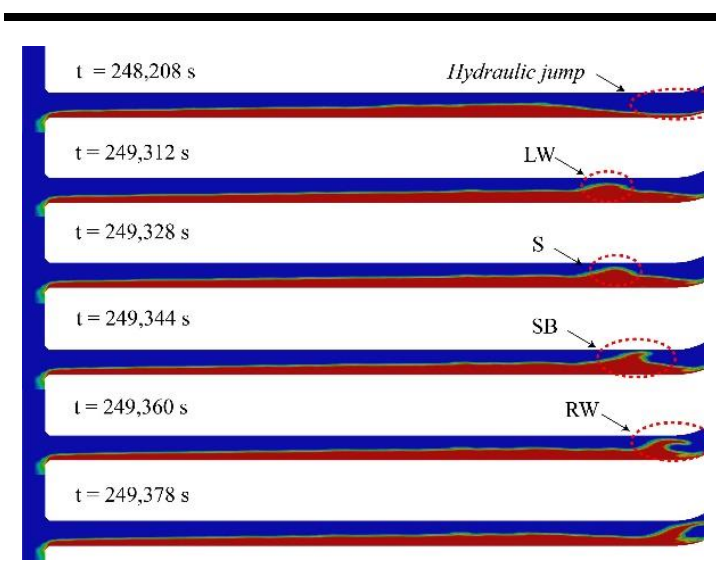

a.

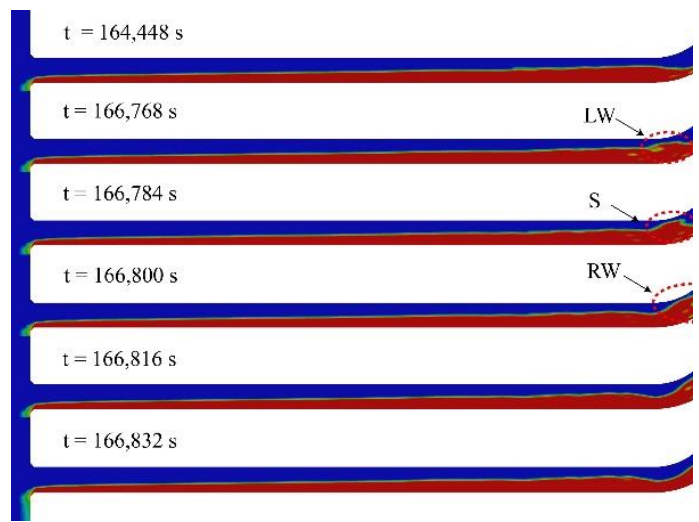

b.

Gambar 6. Onset of slugging pada $\mathrm{J}_{\mathrm{L}}=0,046 \mathrm{~m} / \mathrm{s}$ untuk: a. kloroform-udara dan b. propil asetat-udara

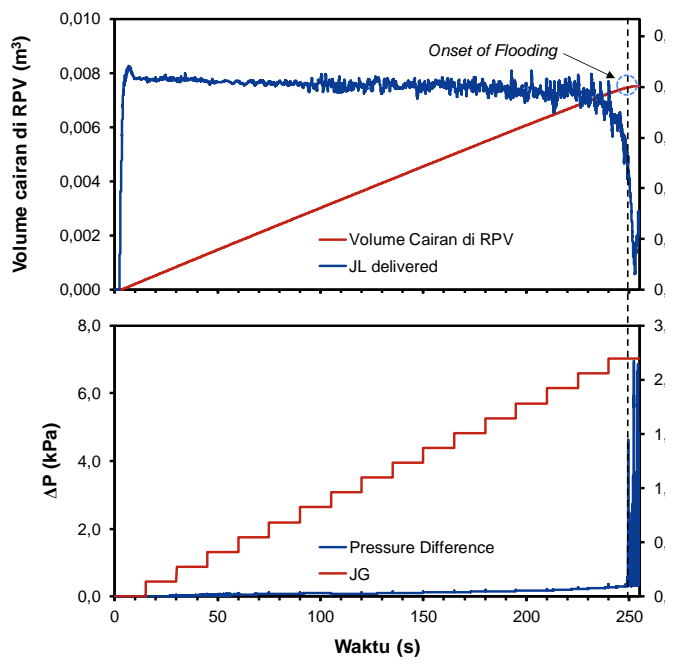

a.

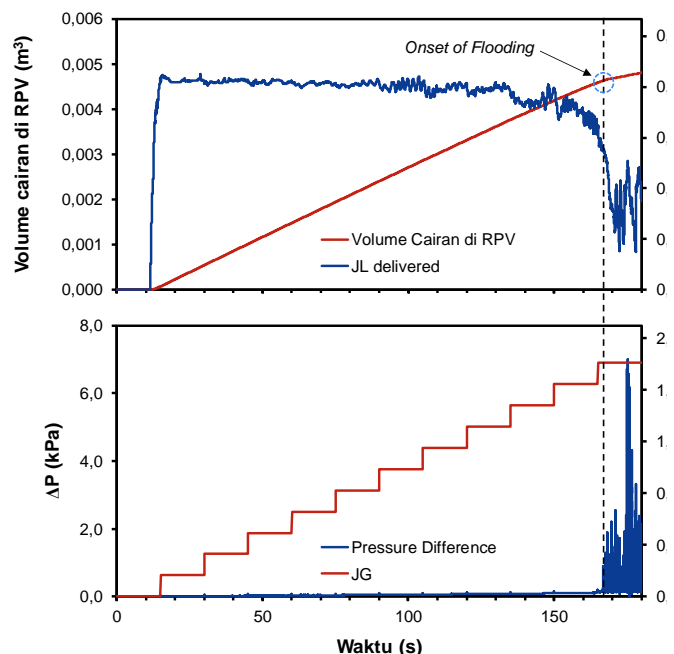

b.

Gambar 7. Variasi parameter aliran terhadap waktu pada $J_{L}=0,046 \mathrm{~m} / \mathrm{s}$ untuk: a. kloroform-udara dan b. propil asetat-udara

Gambar 6 menunjukkan proses pembentukan slug pada kondisi flooding pada $\mathrm{J}_{\mathrm{L}}=0,046$ $\mathrm{m} / \mathrm{s}$. Gambar 6.a menunjukkan pembentukan slug untuk kloroform-udara, sedangkan Gambar 6.b menunjukkan pembentukan slug untuk propil asetat-udara. Gambar 7 menunjukkan variasi parameter aliran untuk kedua kombinasi fluida tersebut. Pada kloroformudara, bydraulic jump terbentuk pada bagian pipa horizontal. Seiring berjalannya waktu, bydraulic jump bergerak menuju belokan dan level air pada bagian subcritical meningkat. Peningkatan level cairan pada subcritical menyebabkan penurunan luas area untuk aliran udara sehingga aliran udara mengalami percepatan. Hal ini menyebabkan peningkatan perbedaan tekanan antara gas dan cairan pada permukaan cairan (interface). Aliran udara yang bersifat turbulen menyebabkan fluktuasi pada perbedaan tekanan tersebut. Gangguan (disturbance) berupa fluktuasi perbedaan tekanan antara gas dan cairan tersebut menyebabkan terbentuknya gelombang di bagian subcritical. Gelombang tersebut berkembang menjadi gelombang besar (LW) hingga akhirnya membentuk slug $(\mathrm{S})$. Keberadaan slug menyebabkan peningkatan $\Delta \mathrm{P}$ akibat terhalangnya aliran 
udara dan menyebabkan penurunan $\mathrm{J}_{\mathrm{L} \text {, Delivered }}$ (Gambar 7.a). Hal yang berbeda terjadi pada propil asetat-udara. Ketika bydraulic jump telah mencapai belokan, level cairan di subcritical meningkat. Fluktuasi perbedaan tekanan antara gas dan cairan akibat turbulensi menyebabkan terbentuknya gelombang kecil. Gelombang ini bergerak ke arah belokan dan menyebabkan hydraulic jump bergerak naik turun di belokan. Ketika bydraulic jump turun, gelombang besar (LW) terbentuk di dekat belokan yang berkembang menjadi slug (S). Pada kondisi onset of flooding untuk $\mathrm{J}_{\mathrm{L}}=0,046$ $\mathrm{m} / \mathrm{s}$, kloroform-udara mengalami penurunan $\mathrm{J}_{\mathrm{L}}$, Delivered yang relatif lebih tinggi dibandingkan propil asetat-udara. Hal ini dikarenakan ketika slug mengalami breakdown (perubahan slug menjadi roll wave yang ditandai dengan singkatan SB pada Gambar 6), jumlah debit cairan yang terbawa oleh aliran gas pada kloroform-udara lebih besar akibat kecepatan superficial flooding gas yang tinggi $\left(J_{\mathrm{G} \text {, flooding kloroform-udara }}=2,63 \mathrm{~m} / \mathrm{s}\right.$, sedangkan $\mathrm{J}_{\mathrm{G} \text {, flooding propil asetat }}=1,81 \mathrm{~m} / \mathrm{s}$ ).

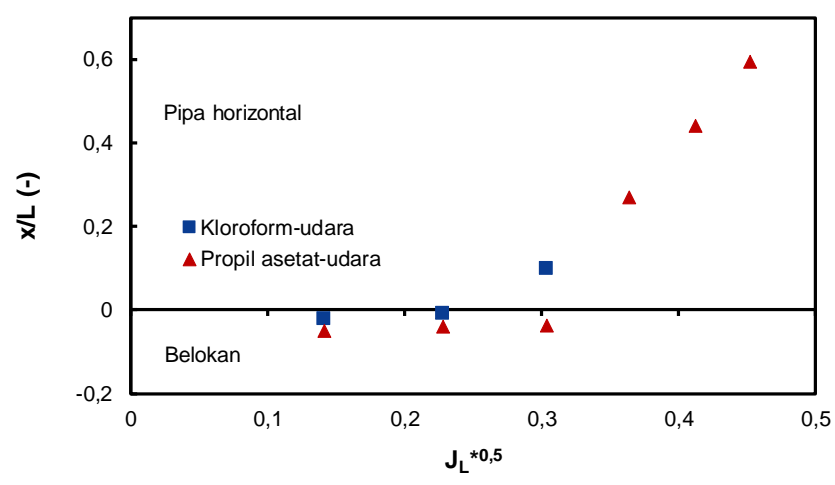

Gambar 8. Locus of slugging kloroform-udara dan propil asetat-udara

Gambar 8 menunjukkan data locus of slugging untuk kloroform-udara dan propil asetatudara. Data tersebut menunjukkan bahwa peningkatan densitas mengakibatkan pergeseran locus of slugging menjauhi lokasi inlet cairan. Perbedaan kecepatan superficial flooding gas, fenomena pembentukan slug, dan locus of slugging dapat dijelaskan dengan menganalisis gaya inersia dari cairan. Aliran kloroform memiliki gaya inersia yang lebih tinggi dibandingkan aliran propil asetat karena densitas kloroform relatif lebih tinggi. Hal ini menyebabkan perlambatan kecepatan aliran cairan akibat wall friction dan interfacial friction (akibat aliran gas) membutuhkan jalur tempuh yang panjang sehingga bydraulic jump terbentuk jauh dari belokan. Pada bagian subcritical, gelombang terbentuk akibat fluktuasi perbedaan tekanan antara gas dan cairan. Karena tingginya gaya inersia dari aliran kloroform, diperlukan gangguan berupa fluktuasi perbedaan tekanan yang tinggi untuk membentuk gelombang. Hal ini menyebabkan flooding terjadi pada kecepatan superficial gas yang tinggi. Keberadaan bydraulic jump yang jauh dari belokan menyebabkan slug awal terbentuk jauh dari belokan. 


\subsection{Pengaruh Viskositas Cairan terhadap Karakteristik CCFL}

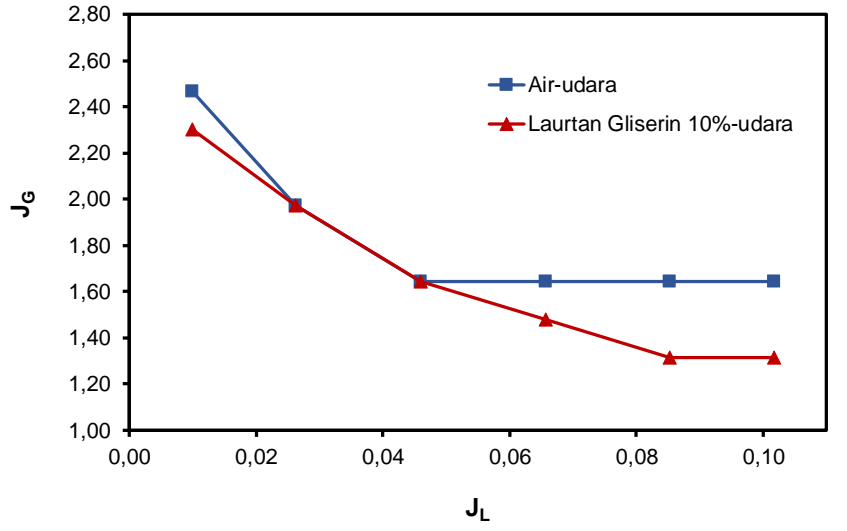

Gambar 9. Data onset of flooding air-udara dan larutan gliserin 10\%-udara

Gambar 9 menunjukkan data onset of flooding antara air-udara dan larutan gliserin 10\%udara. Data onset of flooding dinyatakan dalam kecepatan superficial cairan $\left(\mathrm{J}_{\mathrm{L}}\right)$ dan kecepatan superficial gas $\left(\mathrm{J}_{\mathrm{G}}\right)$. Secara umum, hasil perhitungan numerik menunjukkan bahwa pada kecepatan superficial cairan yang sama, air-udara menghasilkan kecepatan superficial flooding gas yang lebih tinggi dibandingkan larutan gliserin 10\%-udara. Hal ini menunjukkan bahwa peningkatan viskositas cairan akan menyebabkan penurunan kecepatan superficial flooding gas. Hasil tersebut sesuai dengan hasil yang didapatkan oleh Zapke dan Kroeger (1996), Mouza et al. (2005), Pantzali et al. (2007), Prayitno et al. (2012), dan Kinoshita et al. (2011), tetapi berkebalikan dengan pola hasil penelitian Suzuki dan Ueda (1977). Data onset of flooding yang diperoleh juga menunjukkan bahwa perbedaan kecepatan superficial flooding gas yang signifikan terjadi ketika $\mathrm{J}_{\mathrm{L}}$ $>0,046 \mathrm{~m} / \mathrm{s}$. Data tersebut memberikan pola yang sesuai dengan data penelitian Kinoshita et al. (2011) yang menunjukkan bahwa pengaruh viskositas lebih besar pada J yang bernilai tinggi.

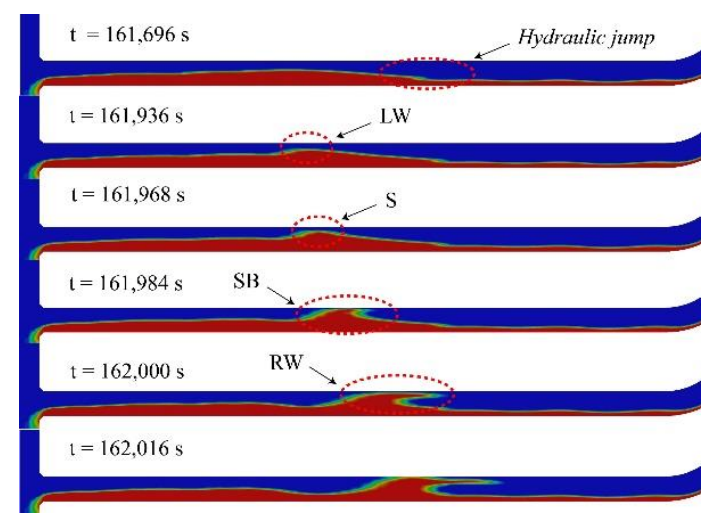

a.

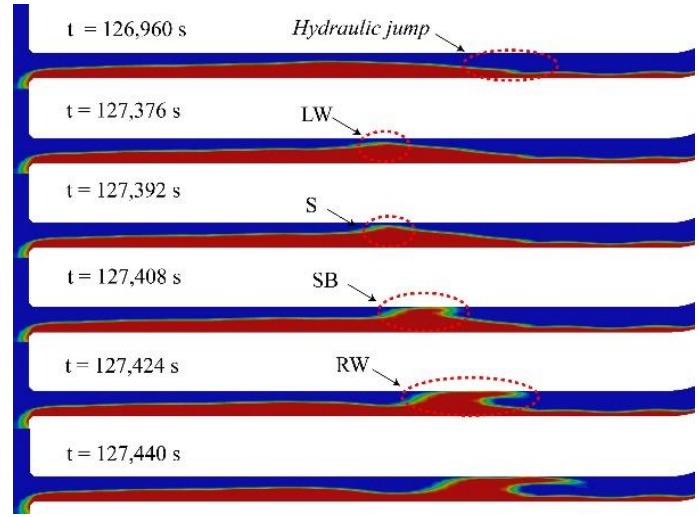

b.

Gambar 10. Onset of slugging pada $\mathrm{J}_{\mathrm{L}}=0,102 \mathrm{~m} / \mathrm{s}$ untuk: a. air-udara dan b. larutan gliserin 10\%-udara 


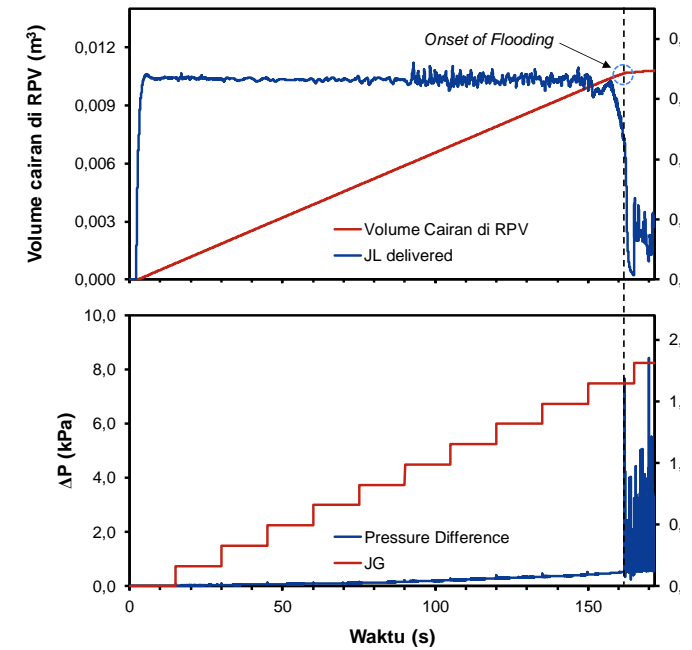

a.

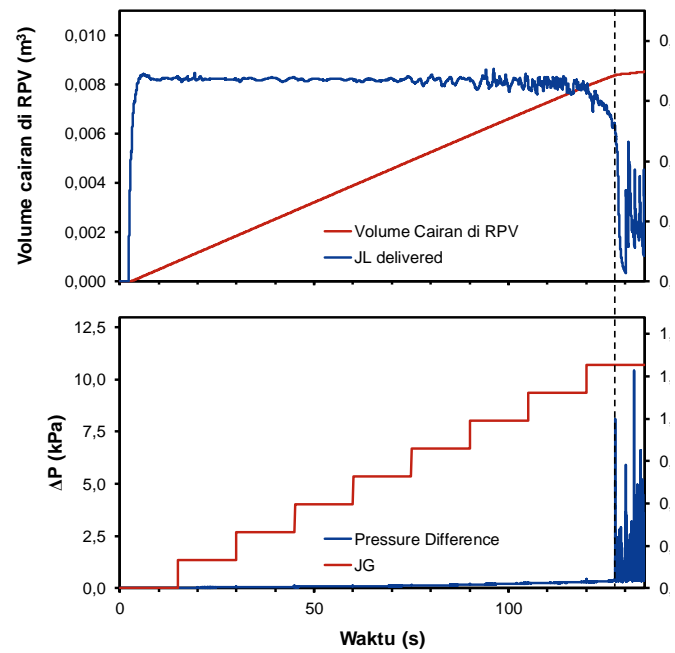

b.

Gambar 11. Variasi parameter aliran terhadap waktu pada $\mathrm{J}_{\mathrm{L}}=0,102 \mathrm{~m} / \mathrm{s}$ untuk: $\mathrm{a}$. air-udara dan b. larutan gliserin $10 \%$-udara

Gambar 10 menunjukkan proses pembentukan slug pada kondisi flooding pada $\mathrm{J}_{\mathrm{L}}=$ 0,102 m/s. Gambar 10.a menunjukkan pembentukan slug untuk air-udara, sedangkan Gambar 10.b menunjukkan pembentukan slug untuk larutan gliserin 10\%-udara. Gambar 11 menunjukkan variasi parameter aliran untuk kedua kombinasi fluida tersebut. Pada air-udara, bydraulic jump terbentuk pada bagian pipa horizontal. Seiring berjalannya waktu, hydraulic jump bergerak menuju belokan dan level air pada bagian subcritical meningkat. Pembentukan gelombang di bagian subcritical diakibatkan oleh gangguan berupa fluktuasi perbedaan tekanan antara gas dan cairan. Gelombang tersebut berkembang menjadi gelombang besar (LW) hingga akhirnya membentuk slug (S). Keberadaan slug menyebabkan peningkatan perbedaan tekanan antara RPV dan SG akibat terhalangnya aliran udara dan menyebabkan penurunan $\mathrm{J}_{\mathrm{L} \text {,Delivered }}$ (Gambar 8.a). Proses yang serupa juga terjadi pada larutan gliserin 10\%-udara.

Berdasarkan Gambar 9 dan Gambar 10, penurunan kecepatan superficial flooding gas akibat peningkatan viskositas cairan disebabkan oleh perbedaan tekanan antara cairan dan gas yang ditimbulkan oleh wall friction (Prayitno et al., 2012). Wall friction yang ditimbulkan oleh viskositas cairan menyebabkan perlambatan aliran sehingga menyebabkan peningkatan perbedaan tekanan antara gas dan cairan. Perbedaan tekanan ini akan bersifat dominan di bagian subcritical karena bagian ini memiliki gaya inersia yang rendah (akibat kecepatan yang rendah). Pada cairan dengan viskositas tinggi, fluktuasi perbedaan tekanan di interface dapat menghasilkan gelombang pada kecepatan superficial gas yang lebih rendah yang nantinya akan berkembang menjadi slug. 


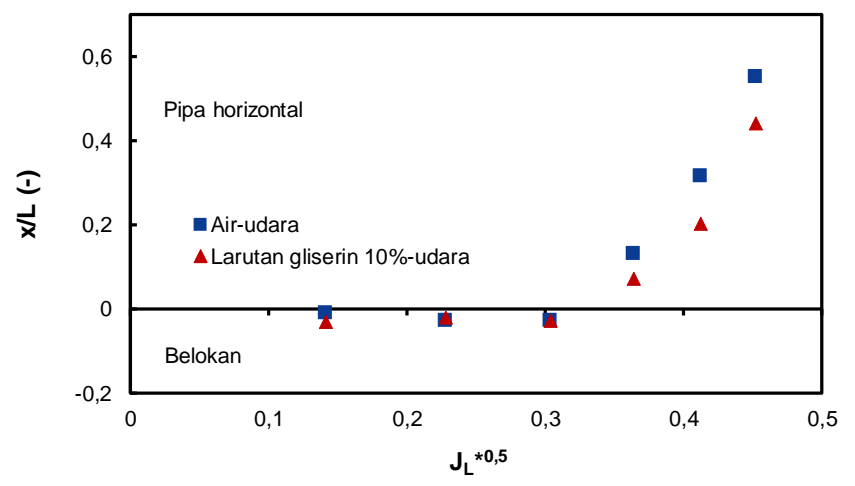

Gambar 12. Locus of slugging untuk air-udara dan larutan gliserin 10\%-udara

Data locus of slugging untuk beberapa nilai JL untuk air-udara dan larutan gliserin 10\%udara ditampilkan pada Gambar 12. Data tersebut menunjukkan bahwa lokasi terbentuknya slug awal pada larutan gliserin 10\%-udara berada lebih dekat dengan belokan dibandingkan air-udara. Data tersebut mengindikasikan bahwa peningkatan viskositas cairan menyebabkan locus of slugging bergeser mendekati inlet cairan. Hal ini dikarenakan cairan dengan viskositas tinggi akan mengalami perlambatan aliran akibat besarnya wall friction. Wall friction akan menyebabkan penurunan gaya inersia cairan sehingga cairan dengan viskositas tinggi akan mengalami perlambatan kecepatan aliran pada jarak tempuh aliran yang lebih dekat. Pada cairan dengan viskositas rendah, perlambatan aliran membutuhkan jalur yang panjang sehingga bydraulic jump dan slug awal terbentuk relatif lebih jauh dari belokan.

\subsection{Pengaruh Densitas Gas Terhadap Karakteristik CCFL}

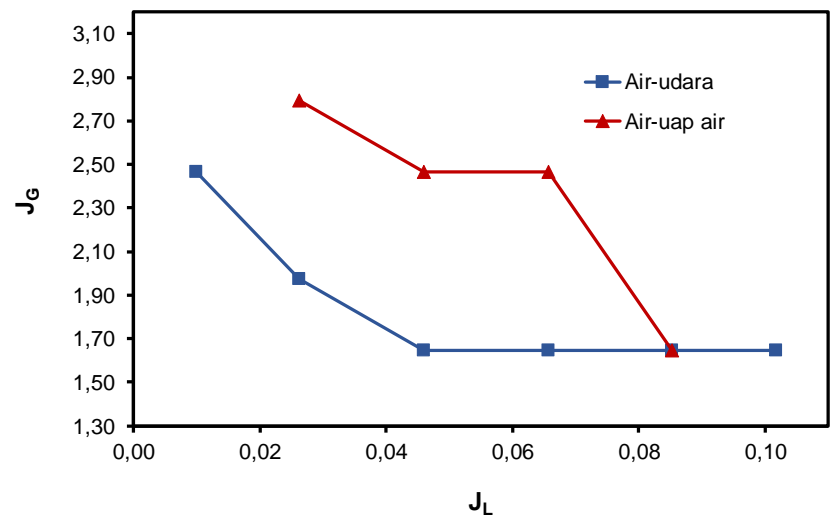

Gambar 13. Data onset of flooding dari air-udara dan air-uap air

Gambar 13 menunjukkan data onset of flooding antara air-udara dan air-uap air. Data onset of flooding dinyatakan dalam kecepatan superficial cairan $\left(\mathrm{J}_{\mathrm{L}}\right)$ dan kecepatan superficial gas $\left(\mathrm{J}_{\mathrm{G}}\right)$. Secara umum, hasil perhitungan numerik menunjukkan bahwa pada kecepatan superficial cairan yang sama, air-udara menghasilkan kecepatan superficial flooding gas yang lebih rendah dibandingkan air-uap air. Hal ini menunjukkan bahwa penurunan densitas gas akan menyebabkan peningkatan kecepatan superficial flooding gas. Hasil yang diperoleh menunjukkan 
pola yang serupa dengan hasil yang diperoleh pada penelitian Zapke dan Kroeger (1996) yang menggunakan pipa vertikal dan miring.

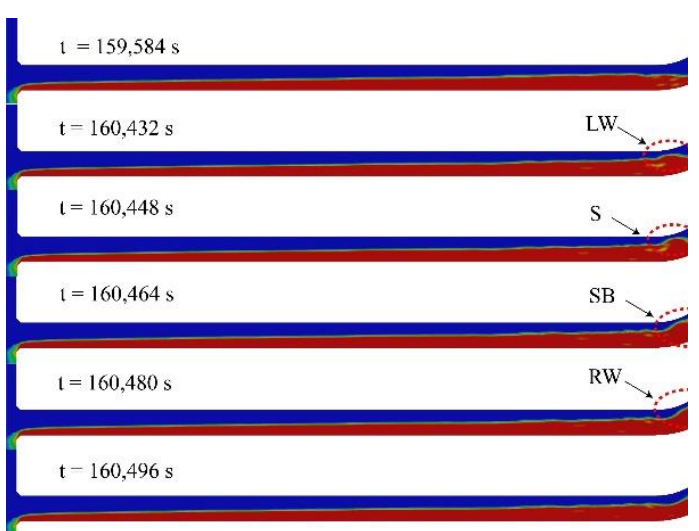

a.

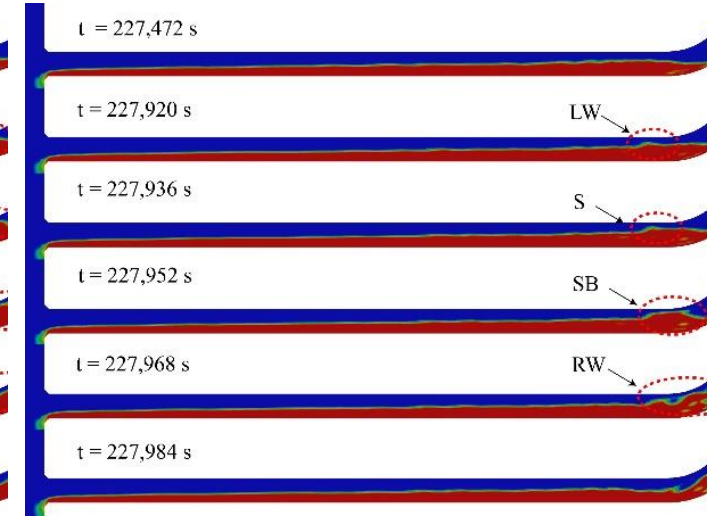

b.

Gambar 14. Onset of slugging pada $\mathrm{J}_{\mathrm{L}}=0,046 \mathrm{~m} / \mathrm{s}$ untuk: a. air-udara dan b. air-uap air

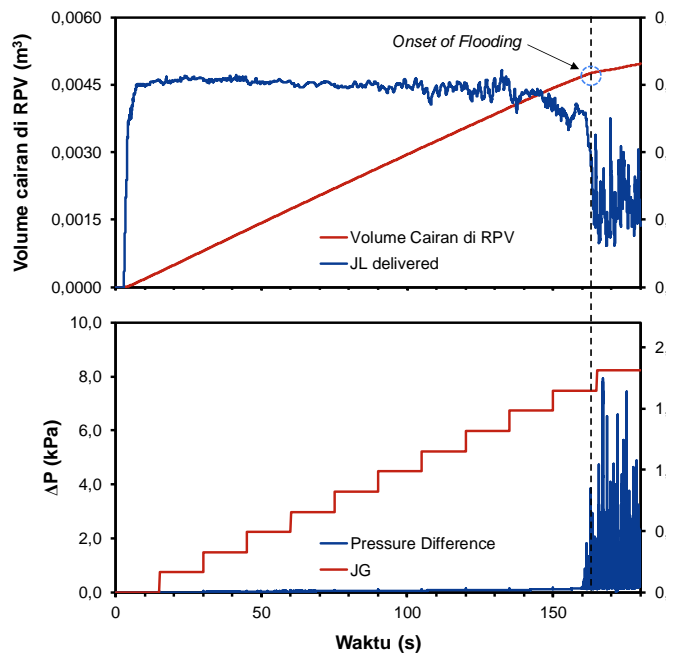

a.

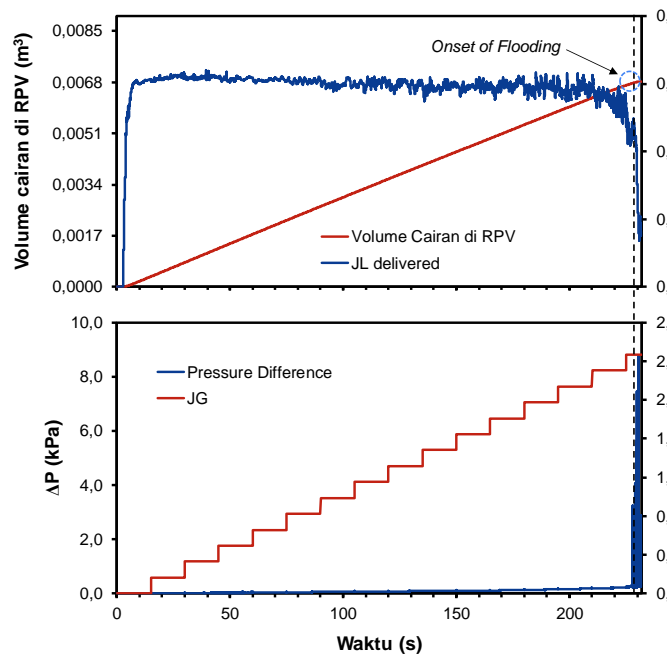

b.

Gambar 15. Variasi parameter aliran terhadap waktu pada $\mathrm{J}_{\mathrm{L}}=0,046 \mathrm{~m} / \mathrm{s}$ untuk: a. air-udara dan b. airuap air

Gambar 14 menunjukkan proses pembentukan slug pada kondisi flooding pada $\mathrm{J}_{\mathrm{L}}=$ 0,046 m/s. Gambar 14.a menunjukkan pembentukan slug untuk air-udara, sedangkan Gambar 14.b menunjukkan pembentukan slug untuk air-uap air. Gambar 15 menunjukkan variasi parameter aliran untuk kedua kombinasi fluida tersebut. Kedua kombinasi fluida menunjukkan proses pembentukan slug yang serupa dengan fenomena pembentukan slug yang terjadi pada propil asetat-udara pada $J_{L}=0,046 \mathrm{~m} / \mathrm{s}$ (Gambar 6.b). Ketika bydraulic jump telah mencapai belokan, level cairan di subcritical meningkat. Fluktuasi perbedaan tekanan antara gas dan cairan akibat turbulensi menyebabkan terbentuknya gelombang kecil. Gelombang ini bergerak ke arah belokan dan menyebabkan bydraulic jump bergerak naik turun di belokan. Ketika bydraulic jump turun, gelombang besar (LW) terbentuk di dekat belokan yang berkembang menjadi slug (S). 
Keberadaan slug menyebabkan peningkatan $\Delta \mathrm{P}$ akibat terhalangnya aliran udara dan menyebabkan penurunan $\mathrm{J}_{\mathrm{L}, \text { Delivered }}$ (Gambar 15.a dan Gambar 15.b).

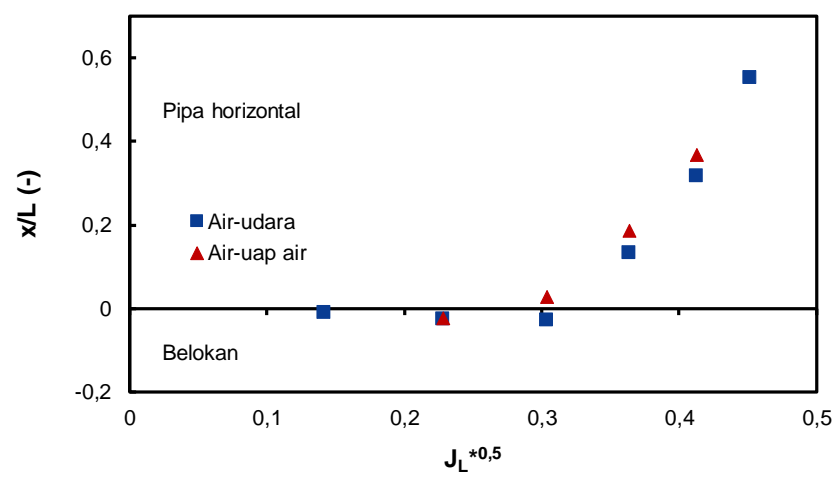

Gambar 16. Locus of slugging air-udara dan air-uap air

Gambar 16 menunjukkan locus of slugging untuk air-udara dan air-uap air. Ketika $\mathrm{J}_{\mathrm{L}} * 0,5 \leq$ 0,228 , lokasi slug awal antara air-udara dan air-uap air berada pada lokasi yang sama. Ketika $\mathrm{J}_{\mathrm{L}} * 0,5$ $>0,228$, locus of slugging air-uap air relatif lebih jauh dari lokasi inlet cairan dibandingkan locus of slugging air-udara. Hal ini menunjukkan bahwa penurunan densitas gas dapat menyebabkan pergeseran locus of slugging menjauhi lokasi inlet cairan.

Peningkatan kecepatan flooding gas akibat penurunan densitas gas dapat dijelaskan dengan menganalisis pengaruh densitas terhadap kondisi aliran gas. Udara memiliki densitas $\varrho$ $=1,225 \mathrm{~kg} / \mathrm{m}^{3}$ dan viskositas $\mu=1,79 \times 10^{-5} \mathrm{~kg} / \mathrm{ms}$, sedangkan uap air memiliki densitas $\varrho=$ $0,554 \mathrm{~kg} / \mathrm{m}^{3}$ dan viskositas $\mu=1,34 \times 10^{-5} \mathrm{~kg} / \mathrm{ms}$. Pada kecepatan aliran dan luas penampang aliran yang sama, udara mengalir dengan bilangan Reynolds yang lebih tinggi dibandingkan uap air. Hal ini menyebabkan udara akan mencapai kondisi turbulen pada kecepatan yang lebih rendah dibandingkan uap air. Keberadaan turbulensi ini menyebabkan gangguan pada permukaan cairan berupa fluktuasi perbedaan tekanan antara gas dan cairan yang dapat mengakibatkan terbentuknya gelombang dan slug. Perbedaan densitas yang besar antara cairan dan gas akibat penurunan densitas gas menyebabkan penurunan interfacial friction. Hal ini menyebabkan perlambatan aliran cairan terjadi pada jarak tempuh yang lebih jauh sehingga gas dengan densitas rendah akan menyebabkan bydraulic jump terbentuk jauh dari belokan. Hal ini juga menyebabkan pembentukan slug awal terjadi pada lokasi yang jauh dari belokan.

\section{KESIMPULAN}

Pengaruh densitas cairan, viskositas cairan, dan densitas gas terhadap karakteristik flooding diteliti dengan menggunakan CFD. Cairan yang digunakan dalam penelitian ialah air, larutan gliserin 10\%, kloroform, dan propil asetat, sedangkan gas yang digunakan ialah udara dan uap air. Geometri penelitian yang digunakan ialah pipa hot leg reaktor PWR tipe German Konvoi skala 1/30. Rangkuman hasil penelitian adalah sebagai berikut.

1. Peningkatan densitas cairan menyebabkan peningkatan kecepatan superficial flooding gas. Hal ini dikarenakan gangguan yang cukup besar berupa perbedaan tekanan antara cairan dan gas diperlukan untuk melawan gaya inersia cairan yang tinggi. Gaya inersia cairan yang tinggi juga menyebabkan pergeseran lokasi bydraulic jump dan locus of slugging menjauhi belokan karena diperlukan jarak tempuh aliran yang jauh untuk memperlambat aliran. 
2. Peningkatan viskositas cairan menyebabkan penurunan kecepatan superficial flooding gas. Peningkatan viskositas mengakibatkan peningkatan wall friction yang menyebabkan perbedaan tekanan antara cairan dan gas meningkat. Peningkatan wall friction juga menyebabkan pergeseran lokasi bydraulic jump dan locus of slugging mendekati belokan karena jalur tempuh yang dibutuhkan untuk memperlambat aliran cairan menjadi relatif lebih dekat.

3. Penurunan densitas gas menyebabkan peningkatan kecepatan superficial flooding gas. Hal ini dikarenakan terjadinya penurunan interfacial friction yang juga menyebabkan pergeseran lokasi bydraulic jump menjauhi belokan sehingga locus of slugging berada jauh dari belokan.

\section{DAFTAR PUSTAKA}

Badarudin, A., Setyawan, A., Dinaryanto, O., Widyatama, A., Indarto, \& Deendarlianto, 2018, Interfacial behavior of the air-water counter-current two-phase flow in a 1/30 scale-down of pressurized water reactor (PWR) hot leg, Annals of Nuclear Energy, 116, 376-387.

Deendarlianto, Höhne, T., Lucas, D., \& Vierow, K., 2012, Gas-liquid countercurrent two-phase flow in a PWR hot leg: A comprehensive research review, Nuclear Engineering and Design, 243(2), 214-233.

Deendarlianto, Höhne, T., Lucas, D., Vallée, C., \& Zabala, G. A. M., 2011,. CFD studies on the phenomena around counter-current flow limitations of gas/liquid two-phase flow in a model of a PWR hot leg, Nuclear Engineering and Design, 241(12), 5138-5148.

Deendarlianto, Ousaka, A., Indarto, Kariyasaki, A., Lucas, D., Vierow, K., Vallee, C., \& Hogan, K., 2010, The effects of surface tension on flooding in counter-current two-phase flow in an inclined tube, Experimental Thermal and Fluid Science, 34(7), 813-826.

Glycerine Producers' Association., 1963, Physical Properties of Glycerine and Its Solutions, Glycerine Producers' Association, New York.

Haynes, W. M., 2016, CRC Handbook of Chemistry and Physics (edisi 97), CRC Press LLC Florence: Taylor \& Francis Group, Boca Raton.

Kinoshita, I., Nriai, T., Tomiyama, A., Lucas, D., \& Murase, M., 2011, Effects of Liquid Properties on CCFL in a Scaled-Down Model of a PWR Hot Leg, Journal of Power and Energy Systems, 5(3), 316-329.

Mouza, A. A., Pantzali, M. N., \& Paras, S. V., 2005, Falling film and flooding phenomena in small diameter vertical tubes: The influence of liquid properties, Chemical Engineering Science, 60(18), 4981-4991.

Murase, M., Utanohara, Y., Kinoshita, I., Yanagi, C., Takata, T., Yamaguchi, A., \& Tomiyama, A., 2012, VOF simulations of countercurrent gas-liquid flow in a PWR hot leg, Journal of Computational Multiphase Flows, 4(4), 375-386.

Ohnuki, A., 1986, Experimental Study of Counter-Current Two-Phase Flow in Horizontal Tube Connected to Inclined Riser, Journal of Nuclear Science and Technology, 23(3), 219-232.

Ousaka, A., Deendarlianto, Kariyasaki, A., \& Fukano, T., 2006, Prediction of flooding gas velocity in gas-liquid counter-current two-phase flow in inclined pipes, Nuclear Engineering and Design, 236(12), 1282-1292.

Pantzali, M. N., Mouza, A. A., \& Paras, S. V., 2007, Study of hydrodynamic characteristics of the liquid layer during counter-current flow in inclined small diameter tubes : the effect of liquid properties, 6th International Conference on Multiphase Flow, Leipzig, 9-13 Juli 2007.

Prayitno, S., Santoso, R. A., Deendarlianto, Höhne, T., \& Lucas, D., 2012, Counter current flow limitation of gas-liquid two-phase flow in nearly horizontal pipe, Science and Technology of Nuclear Installations, 2012. 
Seidel, T., Vallée, C., Lucas, D., Beyer, M., \& Deendarlianto, 2011, Two-phase flow experiments in a model of the hot leg of a pressurised water reactor, TOPFLOW-Experiments: development and validation of CFD models for steam-water flows with phase transfer, Helmholtz-Zentrum Dresden-Rossendorf, Dresden.

Suzuki, S., \& Ueda, T., 1977, Behaviour of liquid films and flooding in counter-current twophase flow-Part 1, Flow in circular tubes, International Journal of Multiphase Flow, 3(6), 517532.

Wallis, G. B., 1969, One-dimensional Two-phase Flow. McGraw-Hill, New York.

Zapke, A., \& Kröger, D. G., 1996, The influence of fluid properties and inlet geometry on flooding in vertical and inclined tubes, International Journal of Multiphase Flow, 22(3), 461472. 